\title{
The efficacy of neighbourhood attitudes as measures of social capital: returning to norms and values and the centrality of networks
}

Link to publication record in Manchester Research Explorer

Citation for published version (APA):

Laurence, J., \& Li, Y. (Ed.) (2015). The efficacy of neighbourhood attitudes as measures of social capital: returning to norms and values and the centrality of networks. In Handbook of Research Methods and Applications in Social Capital (pp. 145-164). Edward Elgar Publishing Ltd.

Published in:

Handbook of Research Methods and Applications in Social Capital

\section{Citing this paper}

Please note that where the full-text provided on Manchester Research Explorer is the Author Accepted Manuscript or Proof version this may differ from the final Published version. If citing, it is advised that you check and use the publisher's definitive version.

\section{General rights}

Copyright and moral rights for the publications made accessible in the Research Explorer are retained by the authors and/or other copyright owners and it is a condition of accessing publications that users recognise and abide by the legal requirements associated with these rights.

\section{Takedown policy}

If you believe that this document breaches copyright please refer to the University of Manchester's Takedown Procedures [http://man.ac.uk/04Y6Bo] or contact uml.scholarlycommunications@manchester.ac.uk providing relevant details, so we can investigate your claim.

\section{OPEN ACCESS}




\title{
The efficacy of neighbourhood attitudes as measures of social capital: returning to $\underline{\text { norms and values and the centrality of networks }}$
}

\author{
James Laurence
}

REFERENCE:

Laurence, J. (2015). The efficacy of neighbourhood attitudes as measures of social capital: returning to norms and values and the centrality of networks.

In Y. Li (Ed.), Handbook of Research Methods and Applications in Social

Capital (pp. 145-164). Cheltenham: Edward Elgar Publishing.

\section{Introduction}

A growing number of studies demonstrate how, after accounting for differences between individuals, the characteristics of communities (e.g. levels of ethnic heterogeneity or socioeconomic disadvantage) in which individuals reside are negatively associated with attitudes towards their neighbours and neighbourhoods; in particular, trust in neighbours (henceforth TiN) (Putnam, 2007; Laurence, 2011). Applying such attitudes as indicators of social capital, these studies have concluded that such characteristics of communities can undermine social capital. Given the rising importance attributed to social capital as a possible explanation for differences in life outcomes between communities, such as in levels of crime (Sampson et al., 1997) or health outcomes (Kawachi et al., 1999), it is important to understand what factors cultivate or erode social capital. However, a significant criticism levelled at such research is how far the variables frequently applied to measure social capital actually capture its presence due to a distinct 'lack of knowledge of the validity of current [social capital] measures' (Moore et al., 2009, p.536; Haynes, 2009; 
Fine, 2010). Considering the purported benefits of social capital, we believe it is crucial to try and understand the efficacy of attitudes such as TiN for measuring social capital in a community.

Exploring the validity of these attitudes as measures of social capital, however, is a difficult task. Firstly, the concept itself remains strongly contested and even reaching a working consensus-based definition has proven elusive (Durlaf, 2002b). Secondly, as Fieldhouse and Cutts (2010, p.296; emphasis our own) discuss, 'social capital is a complex phenomenon that we cannot observe directly' and thus 'various indicators' are used to try and capture it (see also Collier, 2002). However, such has been the breadth of indicators applied in the literature (from voting to fear of crime), with little focus on their validity, that the concept has been accused of being 'the latest buzz word meaning all things to all people... lack[ing] empirical specificity' (Harper, 2001: 12).

We suggest that despite the myriad of definitions, conceptions, and suggested measures, the theoretical foundation of social capital is social networks and the idea that networks possess value (e.g. Bourdieu, 1986; Coleman, 1988; Putnam, 2000; Lin, 2001). These networks form the structural, objective association component of social capital on which the norms and values components rest (Paxton, 1999). Furthermore, it is from actual connectivity that the purported wider benefits of social capital (efficient and diverse information flows, ability to overcome collective action problems, etc.) are believed to emerge (Putnam and Feldstein, 2003). As Putnam (2000, p.19, emphasis our own) states, social capital is '[s]ocial networks and the norms of reciprocity and trustworthiness that arise from them...[a] society of many virtuous but isolated individuals is not necessarily rich in social capital'. We believe a greater conceptual and empirical specificity can 
therefore be achieved by focusing on the 'specific network mechanisms responsible for social capital' with an aim to understand the extent to which those indicators, proxies and outcomes currently applied to capture social capital's presence are actually underpinned by such networks (Burt, 2000, p.346).

Based on this re-focusing onto the network foundations of social capital, if attitudes such as TiN are efficacious indicators of neighbourhood social capital then they should, in theory, also be picking up the presence of networks between neighbours. However, there is little research into whether such 'proxy indicators reflect aspects of people's social connections within neighbourhood settings' (Moore et al., 2009: 536). Potentially, attitudes such as trust may emerge or recede in communities in response to factors unrelated to social connectivity (e.g. Baumgartner, 1988); we may, for example, find communities with high levels of trust but low levels of social connectivity. Would we consider a trusting yet disconnected community high in social capital? If networks form the theoretical heart of the concept, and the purported wider benefits of social capital flow from interaction between actors, then we believe both connectivity and trust are vital for indicating the presence of social capital.

The primary aim of this chapter therefore is to explore the literature's use of attitudes such as $\mathrm{TiN}$ as measures of social capital. We believe that if $\mathrm{TiN}$ is to be used as a proxy/indicator for neighbourhood social capital then it needs to capture both: the norms and trust component and the connectivity component, that rest at the core of the concept. This chapter will be divided into two sections. The first will explore the efficacy of TiN as a measure of social capital. We begin by applying factor analysis to explore whether TiN and measures of (neighbour) social connectivity pick up the same underlying latent factor, 
that is, whether neighbourhood trust and connectivity form two sides of the same coin. Secondly, we will model the individual-level relationships between TiN and measures of connectivity, controlling for individual socio-economic status (SES) and demographics. This will allow us to explore how strongly connectivity is associated with TiN, and whether an individual's SES/demographic characteristics continue to be independently associated with TiN after accounting for social connectivity i.e. whether TiN has sources outside of connectivity. The second section will explore the implications of section one for the use of TiN in the study of the predictors of social capital in current research. We take two key claims from the literature: that higher community ethnic diversity and socio-economic disadvantage undermine social capital, as assumed from their negative relationships with TiN. We test these claims by exploring how far their effects on TiN can be accounted for by differences in levels of social connectivity between communities. If they do undermine social capital both trust and connectivity would be expected to decline.

\section{Theoretical framework}

\section{Measuring social capital: indicators and their theoretical antecedents}

Many scholars have converged on social capital as 'a comprehensive explanation for why some communities are able to resolve collective problems cooperatively while others are unable to bring people together for common purposes' (Brehm and Rahn, 1997: 999). Yet, there remains significant criticism of the use of the concept, particularly towards the measures applied to capture its presence (Haynes, 2009; Fine, 2010). Such criticism often stems from the fact that social capital is considered a complex phenomenon that is difficult 
(if not impossible) to measure directly, which has resulted in a range of indicators, proxy measures, or outcomes being applied to try and capture its presence (Collier, 2002; Fieldhouse and Cutts, 2010). For example, questions on social trust are frequently applied as measures of social capital in the literature. However, trust itself is not actually considered 'social capital but... a close consequence, and therefore could be easily thought of as a proxy' i.e. the presence of trust is believed to indicate the presence of social capital (Putnam, 2001, p.7). However, the use of variables such as trust as a proxy measure becomes problematic if we believe that such variables have multiple sources and that trust may be a close consequence of other factors besides social capital (Fine, 2010). If trust can emerge outside of the presence of social capital its use as a proxy would be compromised i.e. high trust may not reflect high social capital ${ }^{1}$ (Durlaf, 2002a).

If social capital is difficult to observe/measure directly how do we propose to investigate the validity of indicators such as TiN? We suggest that the shared feature at the foundation of almost all conceptions of social capital is social networks (e.g. Bourdieu, 1986; Coleman, 1988; Putnam, 2000; Lin, 2001). Even Putnam's (2000) use of civic association membership was applied as a 'measure of social connectedness', stating there is 'nothing canonically superior about formal associations as forms of social networks' beyond their 'greater ease of measurement' (Putnam, 2001, p.5). Following Paxton (1999, p.93) and Lin (2001), we believe measures of social capital should therefore return to its key components: (1) 'objective associations between individuals', that is, there must be an 'objective network structure linking individuals'; and (2) 'a subjective type of tie', that is, the ties 'between individuals must be of a particular type [e.g.] reciprocal, trusting', etc. This criteria mirrors the cognitive (norms and trust) and structural (networks) components 
(Uphoff and Wijayaratna, 2000), as well as Putnam's definition as 'social connections and the attendant norms and trust' (Putnam, 1995, p.665). Figure 1 (replicated from Paxton (1999)) demonstrates how, theoretically, social capital requires both networks and trust; one without the other does not constitute social capital.

[Figure 1 about here]

Refocusing on the social networks component alongside the cognitive elements (such as trust) is also crucial considering it is through networks that the wider benefits of social capital are believed to be accrued e.g. efficient and diverse information flows, ability to overcome collective action problems, etc. (Putnam and Feldstein, 2003). Criticisms of the social capital literature thus often stem from studies 'extending the notion of social capital beyond its theoretical roots in social relations and social networks', to which we aim to return (Lin, 2001, p.35).

$\underline{\text { Trust in neighbours as a measure of social capital }}$

As mentioned, questions capturing attitudes towards one's neighbours/neighbourhood (especially TiN) have been applied in academic studies (e.g. Putnam, 2007) and by governmental groups (e.g. Harper, 2001) both to measure social capital and study its predictors. Above we outlined the importance of measuring both the trust and networks components of social capital. As Paxton (1999, p.89) emphasises, 'a neighbourhood with high social capital...[entails that] neighbors know each other, talk to each other often, and trust each other' i.e. they need to be trusting and connected. How then 
are attitudes such as TiN applied as proxy measures for the broader concept of social capital?

Trust is conceived of as a core value that forms part of social capital's cognitive component. In Putnam's (2000, p.19, emphasis added) view, social capital is '[s]ocial networks and the norms of reciprocity and trustworthiness that arise from them'. Trust is thus purported to emerge from (or alongside) face-to-face encounters, where the 'multiplicity of interactions lead to the building of knowledge-based trust' (Falk and Kilpatrick, 2000; Marschall and Stolle, 2004: 146; Axelrod, 1984). Based on this, the presence of trust amongst neighbours is applied as a proxy measure for its antecedent interaction/connectivity as well. Therefore, even though only the social values aspect of social capital is being measured this is presumed to be underpinned by social networks, thus capturing both values and networks (Li et al., 2005; Moore et al., 2009).

From this perspective, studies tend to 'measure [social capital's] effects rather than the actual existence of social networks...[t]hat is, 'trust' is an assumed consequence of social networks rather than a measure of the extensiveness of social networks' (Coburn, 2000, p. 142-143). However, considering social capital is both social values and networks, then the use of trust as a proxy rests on the assumption that values such as trust emerge in the presence of networks alone (or that when trust emerges social networks emerge alongside it). If they do then measuring trust in a community should form a valid proxy of social capital. We suggest, however, that whilst local interaction likely leads to the development of trust between residents, potentially, just because a community evinces trust does not necessarily mean residents will be connected. Theoretically, TiN may also emerge from non-connectivity based sources. Baumgartner's (1988) work demonstrates how 
suburban areas 'in which civility prevails and disturbances of the peace are uncommon' possess a strong degree of 'social order', and yet:

‘[t]he order...does not arise from intimacy and connectedness, but rather from some of the very things more often presumed to bring about conflict and violence...[that is]...transiency, fragmentation, isolation, atomisation and indifference among people' (Baumgartner, 1988: 134).

Alternatively, Livingstone, et al. (2010) discuss how factors such as high crime rates in communities can generate distrust between residents. Thus, safe, secure environments, low in crime, can breed trust amongst residents outside of the presence of social networks. Furthermore, as we will outline in more detail below, individuals may perceive others to be trustworthy or not based on their race or class alone (Glaeser et al., 2000). Thus, in theory, communities may exhibit high TiN by virtue of their racial or socioeconomic make-up, independent of how socially connected they are. At the same time, it has been suggested that 'trust...can stem from ethical values that have no social component' (Durlaf, 2002a, p.460). Individuals could therefore evince trust without being socially connected.

If it is the case that trust can emerge without connectivity, we cannot assume therefore that just because a neighbourhood trusts that it will also be connected. Therefore, TiN may not necessarily operate as a proxy for social capital. We outline three possible scenarios for what TiN may capture: (1) TiN captures local social connectivity; therefore, if there is (dis)trust in a community individuals will be (dis)connected and (as applied in the 
literature) TiN would form a valid proxy measure for community social capital; (2) TiN emerges from/alongside local social connectivity; however, crucially, TiN may also emerge without networks. Thus, if there is high connectivity there will likely be high trust; but just because there is high trust does not necessarily mean there will be high connectivity (thus, we cannot assume connectivity based on trust alone); and (3) TiN and local connectivity are unrelated; therefore, TiN does not capture social capital.

Before we continue, an alternative scenario is that $\mathrm{TiN}$ is not a proxy for social capital but actually constitutes social capital itself (Fukuyama, 1995). Potentially, we may find communities high in trust but low in connectivity. Would we still consider such a community high in social capital? Or potentially high in the norms and shared values aspect but low in the social connectivity aspect? Most definitions of social capital merge 'social networks and the associated norms of reciprocity and trustworthiness' into a single concept and do not discuss whether either/or is sufficient to be classed as social capital (Putnam, 2007, p.137). However, as discussed, we believe networks have to be present for us to class an area as high in social capital as without the networks underpinning trust the wider benefits attributed to social capital (e.g. efficient information flows, etc.) are much less likely be accrued.

Implications for analysing predictors of social capital: the case of Community Ethnic diversity and Disadvantage

We have thus outlined the importance of measuring networks, alongside social values such as trust, for capturing the presence of social capital, as well as highlighting the theoretical possibility that a trusting community may not necessarily be a socially connected one. We 
turn now to exploring the implications of this discussion for two key relationships outlined in the literature: that higher rates of community (1) ethnic diversity and (2) disadvantage are negatively associated with neighbourhood attitudes ${ }^{2}$ (especially lower TiN). Based on the assumption that such attitudes form valid indicators of social capital, these studies often conclude that diversity and disadvantage undermine community social capital.

To account for these relationships, studies have drawn on a range of literatures suggesting that the negative effects of diversity and disadvantage on attitudes such as trust comes through channels of social connectivity between residents. In terms of diversity, as Uslaner (2010, p.2) notes, scholars tend to argue that 'diversity...breeds aversions to interaction with people of different backgrounds' and thus individuals 'choose to participate less in racially mixed communities', resulting in lower trust (Alesina and LaFerrara, 2000, p.891). Alternatively, homophily is often cited as an explanation, suggesting individuals prefer interaction with similar individuals (e.g. in terms of race, income, etc.) and thus co-habiting amongst lower proportions of co-ethnics results in a smaller pool of ties with whom individuals will interact (Stolle, et al., 2008; McPherson et al., 2001). Therefore, connectivity is posited to decrease alongside trust with rising diversity as it would inhibit interaction between residents, thus undermining social capital.

Similarly, higher community disadvantage is believed to erode social networks through apathy, insecurity, and an unwillingness to engage in neighbourhood activities; conversely therefore, 'more advantaged places have higher levels of informal social ties that bind neighbors together' (Ross et al., 2001, p.572-73; Sampson et al., 1997). As Letki (2008) suggests, 'deprivation and disorder erode formal and informal interactions, which in turn lowers interpersonal trust' (p. 104). Under these applied theories, the lower TiN in 
disadvantaged communities would also be underpinned by weaker connectivity. If this is the case, the current claims that disadvantage undermines social capital would be (in our view) valid.

No study, however, has tested the extent to which the lower TiN in diverse and/or disadvantaged communities is accounted for by weaker patterns of connectivity. Therefore, whether diversity and/or disadvantage do actually undermine both $\mathrm{TiN}$ and social connectivity (and thus social capital), as theoretically predicted, remains largely unknown. The problem is, there are a number of theories which suggest diversity and disadvantage may undermine TiN outside of a social connectivity-pathway. In terms of diversity, it is posited that trust is implicitly more likely to develop within (rather than between) ethnic groups. Messick and Brewer (1983: 27-28; emphasis in original) note that individuals 'perceive other in-group members in generally favorable terms, particularly as being trustworthy, honest, and cooperative'. Glaeser et al. (2000) also demonstrates lower levels of honesty and reciprocity in inter-racial exchanges. Therefore, 'ethnic and racial differences [may] discourage the reliance on the behavior of one's neighbors, friends and colleagues' (Messick and Kramer, 2001: 100). As such, trust may be higher in homogeneous communities simply by virtue of individuals perceiving their neighbours to be more trustworthy, not necessarily through higher social connectivity. Disadvantage may also affect trust directly (outside of connectivity) as such communities are posited to 'expose residents to a daily dose of petty crime, concentrated physical decay and social disorder' which 'in turn leads to a constellation of negative psychological $\underline{\text { states....[including] feelings of anxiety and fear, alienation from neighbours [and] lack of }}$ 
trust in others' (Oliver and Mandelberg, 2000, p. 576, emphasis our own). Again, declining TiN without recourse to a social connectivity explanation.

The literature therefore contains theoretical frameworks suggesting the effects of diversity and disadvantage may come through both social and non-social connectivity pathways. There is therefore no reason to necessarily assume that the negative effects of diversity and disadvantage on TiN demonstrated in the literature indicate that they undermine social capital (i.e. both the values and networks components).

\section{Summary and outline of analysis}

The main aim of this paper is to: (1) test the efficacy of neighbourhood attitudes, in particular TiN, as measures (i.e. proxies/indicators) of social capital; and (2) explore the implications of this for studying the predictors of social capital, especially the effects of community ethnic diversity and disadvantage. We follow Paxton (1999), suggesting social capital requires two key components: both social networks and a subjective type of tie (such as a trusting one). Therefore, for neighbours to possess high social capital requires residents to be both connected to, and trusting of, one another. To explore these aims we begin by analysing the inter-relationships between attitudes of TiN and levels of social connectivity, including: employing factor analysis methods to test whether trust and connectivity capture the same, underlying latent construct i.e. whether if an individual trusts they are also connected; as well as examining how far measures of connectivity are related to trust by modelling the individual-level relationships between connectivity and TiN, controlling for SES and demographics. Combined, these tests will allow us to gauge the efficacy of TiN in capturing levels of social connectivity. 
We will then explore the implications of this for investigating the predictors of social capital more generally. We take two key relationships from the literature: that community ethnic diversity and disadvantage are negatively associated TiN, and test the claims that they undermine social capital by testing how far measures of social connectivity mediate the negative effects of diversity and disadvantage on TiN. If such community characteristics do undermine social capital, as is claimed, much of their negative effect (and statistical significance) should be accounted for by differences in levels of social connectivity between communities.

There are two potential issues with the following analysis. Firstly, although we will be using measures of social connectivity as predictors of TiN we are not necessarily making a unidirectional causal claim that trust emerges from the formation of ties. In theory, 'the more we connect with other people, the more we trust them, and vice versa' (Putnam, 1995, p.665; Brehm and Rahn, 1997). Alternatively, trust and networks may emerge simultaneously. Whilst this is an important debate, ultimately our aim is to explore the associations between trust and networks i.e. how far TiN (as a proxy for social capital) picks up connectivity. Therefore, we set aside issues of causality for the moment. Secondly, a key assumption of this chapter is that for greater TiN to function as a measure of social capital it should also capture more ties with neighbours, and more frequent interaction between them (Paxton, 1999). However, TiN may not simply be associated with greater connectivity between neighbours but only with specific types of ties with neighbours e.g. it is not simply connecting with neighbours but connecting through participation in local civic-groups for instance. Therefore, whilst TiN may not form a valid proxy for all ties with 
neighbours it may form a valid proxy for civic tie connectivity with neighbours. Unfortunately, our data precludes a detailed test of this.

\section{Data and methodology}

\section{Datasets and sample}

To investigate these issues we use the 2000-01 General Household Survey (GHS), a nationally representative dataset of England. This dataset is particularly useful as it contains both: a measure of TiN, and a range of measures of the size of, and level of activity within, an individual's local social networks. Our community-level data is predominantly taken from the 2001 UK Census, except for our measure of disadvantage (the 2004 Index of Multiple Deprivation (IMD)) which was created by the then Office of the Deputy Prime Minister (ODPM) (see below).

\section{$\underline{\text { Key dependent and independent variables (individual-level) }}$}

Our key dependent variable, frequently applied as a measure of social capital, is trust in neighbours (TiN): individuals are asked whether they 'trust...most, many, a few, or none of the people in your neighbourhood'. As discussed, our primary aim involves investigating the relationship between attitudes of $\mathrm{TiN}$ and the social networks that lie at the core of social capital. The GHS contains a range of measures of an individual's ego-centric social network that will allow us to explore these ideas ${ }^{3}$. Table 1 summarises the full set of local social connectivity measures available, including measures of 'close' tie connectivity ${ }^{4}$.

These measures will allow us to test our key contention for the use of TiN as a proxy for community social capital: that a neighbourhood rich in social capital should be 
one in which individuals are both connected to, and trust, one another (Paxton, 1999). The GHS provides measures of interaction/connectivity with neighbours in particular, allowing us to explore the specific relationship between trust of, and connectivity to, neighbours. However, they also provide us with a wider array of local tie measures (including local close friends or local familial ties).

[Table 1 about here]

$\underline{\text { Key community-level independent variables }}$

To measure diversity we use the Simpson's (1949) Index of Fractionalisation. The SDI captures 'the probability of two randomly chosen individuals within one neighbourhood being members of different racial groups' (Letki, 2008, p.110). We group the Census ethnicity categories into 9 sub-groups, including: White, Pakistani, Bangladeshi, Indian, Asian Other/Mixed, Black Caribbean/Mixed/Black Other, Black African/Mixed, Chinese, and Other/Mixed ${ }^{5}$. To measure socio-economic disadvantage we use the 2004 IMD. This is a composite index of seven domains of disadvantage, including: income, employment, health, education, housing, crime, and the living environment (ODPM, 2004).

$\underline{\text { Individual- and community-level controls }}$

To adjust for possible confounding community characteristics we control for: rate of residential turnover (calculated by adding together the inflow and the outflow of persons in an area over a year) per 1,000 people; density of population per hectare; \% aged 65 years old and above; and whether the neighbourhood is found in a town, or urban, (compared to a 
rural) area. At the individual-level we control for: length of time lived in the neighbourhood, age, gender, household income, whether respondent owns a private vehicle, education, Socio-Economic Class, ethnicity, economic status (employed, unemployed, long-term disabled, home-person, retired), marital status, children in household, UK born, and housing tenure.

\section{Modelling methods and spatial scale of community}

Our dataset contains two-levels of analysis: individuals nested within communities. To avoid biased standard error estimates of our community-level variables we apply hierarchical (multi-level) random-intercept models $^{6}$ (Snijders and Bosker, 1999). As our outcome of TiN is ordinal, we apply generalized linear latent and mixed models to account for this. For the purposes of this analysis, we will measure all characteristics of the neighbourhood/community at the Middle Super Output Area (MSOA: mean: 7,200 residents) level. The size of MSOAs is somewhat broader than what we might consider the neighbourhood ${ }^{7}$. However, whilst less spatially accurate, using the MSOA produces a data structure in which a far lower proportion of communities have only one respondent $(6 \%)$ and leads to a larger $\underline{\mathrm{n}}$ per level- 2 unit (on average 5 residents per MSOA) to increase the robustness of our models ${ }^{8}$. Standardised coefficients are reported to allow for ease of comparison between the relative effects of different types of connectivity. 


\section{Results}

Section one: the inter-relationships between trust in neighbours and social connectivity

This first section empirically explores the inter-relationships between TiN and measures of social connectivity. We begin by applying exploratory factor analysis between social connectivity measures and TiN (Table 2$)^{9}$. As discussed, if TiN is purported to measure social capital, and social capital is composed of both shared values and networks, it should, in theory, load robustly on to measures of (neighbour) connectivity i.e. both local trust and connectivity should pick up the same underlying, latent factor (of neighbourhood social capital).

[Table 2 about here]

The only connectivity measures that load above .4 with TiN are knowing and speaking to neighbours. However, the Eigen Value is below 1, and an Alpha Score of the three variables is 0.5 . This suggests that they are related (as theoretically predicted); however, these results are not strong enough to convince us that social (especially neighbour) connectivity essentially captures the same underlying factor as TiN.

This provides the first line of evidence that we should not simply assume, empirically, that just because an individual trusts their neighbours that they possess high levels of connectivity with them. The second test is how far (and which) individual-level measures of social connectivity are associated with TiN, and whether these hold after controlling for socio-demographic characteristics at the individual-level. Table 3 shows the results of a step-wise ordered logistic regression analysis in which we build up our full 
model of social connectivity measures and their relationships with TiN, including: the baseline model without connectivity measures (Model 1); local close relatives (Model 2); local crisis contacts (Model 3); local close friends (Model 4); neighbour interaction (Model 5); and neighbour ties (Model 6).

[Table 3 about here]

Table 3 reveals a number of key points. Firstly, knowing more neighbours, and speaking to them more frequently, are very strongly associated with TiN i.e. individuals connected to their neighbours are very likely to trust them. We also find that possessing more local close friends and crisis contacts are significantly associated with TiN i.e. whilst neighbour connectivity is most strongly associated with TiN, other forms of connectivity also evince associations. Secondly, we find that a large portion of the coefficient size (and all the statistical significance) of a number of socio-demographic measures are fully accounted for by how socially connected an individual is e.g. the greater TiN reported by women, married individuals, or those in the community for more years (Model 1) is almost entirely underpinned by higher connectivity with neighbours.

These results thus provide strong evidence that if an individual is connected, especially to their neighbours, they exhibit TiN. Yet, they also provide further evidence against using TiN as a proxy for social capital. Firstly, we find a significant portion of the variance in TiN remains unaccounted for (the pseudo R-Squared in Model 6 is 0.158). Secondly, many of the socio-demographic controls remain significantly related to TiN even after accounting for levels of social connectivity. In fact, age has a very strong relationship 
with trust, second to knowing more neighbours; yet almost none of its relationship to trust is underpinned by connectivity. Potentially, this may result from not accounting for a complete range of types of social connectivity. However, more problematic still, some individual-level SES controls actually exhibit changes which suggest their relationship with trust is suppressed by lower levels of connectivity. For example, the positive effects of possessing a degree or above, or possessing a higher household income, actually increase and become more significant when we control for the level of connectivity. In other words, richer, more educated individuals tend to trust $\underline{\text { more }}$ of their neighbours yet at the same time know fewer and speak to them less frequently than less well-off or less qualified individuals ${ }^{10}$.

At the outset of this chapter we detailed how for TiN to form an efficacious proxy for community social capital, an individual that exhibits (dis)trust would also need to exhibit dis(connectedness). However, these findings suggest that, empirically, we should not assume a trusting individual is necessarily a connected one. Instead, whilst connected individuals are much more likely to trust neighbours, just because an individual trusts their neighbours does not necessarily mean they are connected to them. We can see idea this summarised in a cross-tabulation between the proportion of neighbours an individual knows with the proportion they trust (Table 4): for example, whilst $83 \%$ of individuals who know many/most of their neighbours trust many/most of their neighbours, around $40 \%$ of individuals who know none/a few of their neighbours also trust many/most of their neighbours. Again, whilst individuals who are connected tend to trust, just because an individual trusts does not necessarily mean they are connected. Instead, TiN can emerge alongside a number of other factors (e.g. education, age) that have very little (or even a 
negative association) with connectivity; thus, to assume that just because someone trusts that they are also connected would be incorrect.

[Table 4 about here]

Section two: do community diversity and disadvantage undermine social capital? A test of the literature's claims

Section two concerns the implications of the findings from section one for studying the predictors of social capital. Previously, we outlined two core findings from the literature: that higher ethnic diversity and socio-economic disadvantage are negatively associated with TiN. Based on this, studies have suggested that diversity and disadvantage undermine social capital. However, we have shown that just because individuals report trust in their neighbours does not necessarily mean they'll be connected to them; furthermore, just because a variable is positively related to TiN does not necessarily mean it is positively related to connectivity e.g. individual-level education. We intend to explore the implications of this for the literature by testing the claims that diversity and disadvantage undermine social capital.

To test whether the lower TiN exhibited in diverse/disadvantaged communities indicates lower social capital in the neighbourhood we begin by creating a baseline model, containing all individual- and community-level controls (Model 1, Table 5). We then include, in a stepwise fashion, our measures of social connectivity. If diversity or disadvantage undermines community social capital (i.e. that both trust and networks decrease with increasing diversity/disadvantage) then we would expect a large portion of 
the size and statistical significance of their association with TiN to be accounted for (i.e. mediated) when adding our measures of social connectivity. In other words, to what extent is the higher (lower) trust in homogeneous/advantaged (diverse/disadvantaged) communities underpinned by higher (lower) connectivity?

[Table 5 about here]

We observe that, between our baseline model (Model 1) and Model 6 (controlling for all types of local connectivity), the effect of diversity is reduced in total by $35 \%$ and is also reduced to non-significance. Particularly important for accounting for the negative relationship between diversity and $\mathrm{TiN}$ is speaking to, and knowing more, neighbours. These findings suggest diversity is therefore negatively associated with both the size of (and level of activity within) an individual's local networks, and differences in connectivity across levels of diversity accounts for a large amount of the differences in trust. In other words, the trust exhibited in homogeneous areas is strongly underpinned by connectivity with neighbours ${ }^{11}$.

In terms of disadvantage, in Model 1 we observe that the IMD 2004 possesses a strong, negative association with TiN. However, on controlling for local connectivity (especially knowing neighbours) we find the negative effect actually increases by $40 \%$. Thus, disadvantage is negatively associated with trust but positively associated with a number of local connectivity measures (especially knowing neighbours ${ }^{12}$ ); the fact that individuals know more neighbours in disadvantaged communities therefore suppresses its negative effect on TiN. 
How do these findings impact claims in the literature that diversity and disadvantage undermine social capital? We find, as demonstrated in much of the community-level literature, that ethnic diversity is negatively associated with TiN. However, a large proportion of the coefficient size (and all its statistical significance) can be accounted for with the inclusion of our measures of local, especially neighbour, connectivity. In other words, diversity's negative association with TiN comes through its negative association with connectivity. These findings suggest diversity does appear to undermine social capital insofar as the lower TiN in diverse communities is accounted for by lower connectivity i.e. with full controls, homogeneous areas exhibit comparatively higher trust and connectivity whilst diverse areas lower trust and connectivity ${ }^{13}$.

These results also suggest that, based on the concept of social capital as networks and values, increasing disadvantage does not necessarily undermine local social capital. Whilst higher levels of disadvantage are strongly negatively associated with TiN, they are also positively associated with neighbourhood connectivity, which actually suppresses the negative effect of disadvantage on trust ${ }^{14}$. Therefore whilst individuals may report higher (or lower) trust in affluent (disadvantaged) communities, they are likely to report few differences in levels of connectivity (and perhaps even greater connectivity in disadvantaged areas).

\section{Discussion and conclusion}

We investigated the efficacy of neighbourhood attitudes, especially $\mathrm{TiN}$, as frequently adopted measures of social capital (at least in the neighbourhood). Following Paxton (1999) and Lin (2001), we believe social capital is comprised of (or requires at least) two key 
components: an objective network link/tie and that such a tie has subjective value e.g. it is reciprocal or trusting. The social network component rests at the heart of nearly all definitions of social capital, and is particularly important considering that the wider benefits attributed to the concept require actual ties to be accumulated. Based on this, for TiN to operate as a proxy for social capital we suggested that: as well as (directly) capturing the values between residents, it also needs to (indirectly) capture the networks. Our results suggest, however, that TiN does not function as an effective proxy measure for social capital. Instead, whilst individuals who are connected to their neighbours will likely trust them (i.e. possess neighbourhood social capital), just because they trust their neighbours does not necessarily mean they will be connected to them; trust appears to emerge without attendant connectivity.

This, as shown, has significant implications for the literature's analysis of the predictors of social capital. Firstly, we find that a number of individual-level characteristics have strong relationships with TiN. However, based on these associations alone, we cannot easily infer the extent to which such individuals are also connected to their neighbours (and thus, in theory, possess higher social capital). For example, the greater TiN evinced by married individuals does appear to denote greater connectivity, as their positive association with TiN is almost completely accounted for by their greater connectivity. Yet the relationship between education or social class and TiN, two of the strongest associations, is entirely unrelated to connectivity. In fact, such higher status individuals actually appear to be less connected compared to those with less education and lower social class, and accounting for these differences increases their positive association with TiN. We 
demonstrate that this issue of inferring social capital from TiN alone has important implications for the literature exploring the community-level predictors of social capital.

The debate into the relative deleterious effects of community ethnic diversity or disadvantage on social capital (as predominantly measured by attitudes of neighbourliness) has received considerable attention. However, we have shown that, insofar as social capital requires both social values and connectivity, assumptions regarding their relative effects on social capital may be incorrect. By exploring how much of diversity's and disadvantage's association with TiN can be accounted for by their association with connectivity, we find that it is diversity which is more likely to undermine social capital compared to disadvantage (or at least the type of social capital based on a trusting and connected neighbourhood). Therefore, even though diversity's relationship with TiN is weaker than disadvantage's, the lower TiN evinced by individuals in more diverse communities can be accounted for by their lower connectivity (again, not assuming causality). The lower TiN in disadvantaged communities, however, is almost entirely unrelated to how connected residents are to one another. In fact, as discussed, residents of disadvantaged communities tend to report somewhat greater local connectivity (although this does not necessarily mean they do not have low social capital ${ }^{15}$ ).

This draws out a number of conclusions. We believe it would be difficult to argue that social networks are not a vital pre-requisite (along with trust) for social capital, resting, as they do, at the theoretical heart of the concept. These results suggest that capturing only one component of social capital (e.g. trust) as a proxy for its presence can lead to premature conclusions regarding levels of social capital, as well as an understanding of what cultivates or erodes social capital. If a characteristic is negatively associated with TiN, this can 
demonstrate that it also undermines social capital (as in the case of community diversity); however, it should not be taken as a given that it will also undermine the associated networks (as with community disadvantage). In other words, one cannot assume a characteristic undermines social capital based on using $\mathrm{TiN}$ alone as trust appears to emerge at higher (lower) levels without attendant (dis)connectivity. Yet, at the same time, connectivity should not simply become an alternative proxy measure for social capital in the place of trust. As demonstrated, whilst connected individuals are likely to trust their neighbours, we also observe that just because something is positively associated with connectivity does not necessarily mean it is also positively associated with trust. If we were to simply look at connectivity as a proxy for social capital, for example, we would have assumed communities with higher disadvantage would have higher social capital, or more educated/higher social class individuals lower social capital. By observing their association with trust as well, we actually know that disadvantaged communities possess comparatively less trust (than affluent communities), while educated, higher social class individuals possess more trust (than less educated, lower social classes). We believe that what is required are measures of both shared values and norms, and networks, to fully capture the theoretical components of social capital, insofar as both form the core of the concept of social capital.

This idea applies to the range of proxies/indicators of social capital often applied in the literature e.g. voting, contacting public officials, low fear of crime, generalized trust etc. (Harper, 2001). Whilst such attitudes/behaviour may emerge from networks rich in norms of reciprocity and trustworthiness (and thus be indicative of social capital's presence), they likely have sources outside of social capital e.g. civic values instilled through parents, 
unrelated to one's social networks. In theory, individuals may hold any of these attitudes or perform any of these behaviours and yet be completely disconnected. Simply assuming they indicate social capital may not only be erroneous but also dilutes the conceptual power of social capital, such that any positive outcome often becomes an indicator of its presence (Durlaf, 2002b). We suggest the need to develop more conceptually and empirically precise measures of social capital, grounded in its theoretical framework of norms, shared values and especially networks, to better understand both social capital's outcomes and predictors. However, these findings also beg a number of key questions regarding measures of social capital more generally.

Firstly, this chapter has assumed, drawing on the theoretical literature, and the use in studies of TiN as a proxy for social capital, that a trusting and connected community contains greater amounts of social capital which will benefit both residents and the community as a whole. However, the relative benefits of say, trusting neighbours versus being connected to them, are less well understood. Whilst based on theory it is the combination of the two that should produce the best outcomes, perhaps trust alone is important, or trust and connectivity are important for different outcomes. Potentially, the importance of social capital within the community is relative to its context. High trust and connectivity in a disadvantaged community may help overcome local problems (such as reducing crime), or provide access to wider sources of information. However, high social capital may matter far less to residents of affluent communities who likely have more extensive sources of social capital outside their community, or for whom far fewer problems are experienced within the community itself. Furthermore, although diversity appears to undermine (local) social capital (i.e. values and connectivity) and disadvantage 
only the values component, many studies have demonstrated that community disadvantage negatively predicts a host of other frequently applied indicators of social capital e.g. organisational participation, voting, social support, etc., while diversity's association with these is far less clear (e.g. Letki, 2008). Does this suggest that these are not efficacious proxies for (or outcomes of) social capital, or that a trusting-connected neighbourhood captures only one type of (local) social capital, with specific outcomes, whilst things like organizational involvement form another type of social capital? Again, without finer measures of the networks and norms posited to rest at the core of the concept it is difficult to answer. Similarly, focusing on indicators such as TiN (and its associated levels of connectivity) may miss broader outcomes. Whilst trust and connectivity may decline in diverse communities, opportunities to form bridging-ties are likely much higher and, insofar as such bridging-ties yield different benefits (e.g. greater generalized trust (Putnam, 2000)), the cost of lower neighbour trust may be offset by benefits elsewhere. There are also potential weaknesses in simply using separate measures of trust in, and connectivity to, neighbours. For example, in disadvantaged communities, do residents know one another more but trust one another less? Or do they trust residents they do know but strongly distrust those they don't? Based purely on these measures we cannot tell. Lastly, the current study, along with much of the literature on the community-level predictors of TiN, applies cross-sectional analysis. The apparent associations between diversity, disadvantage and trust and connectivity could potentially be a product of endogeneity. It may be that individuals less inclined to form part of their community are more likely to move into diverse neighbourhoods if, for example, there are other benefits, such as cheaper housing or better locations. Further analysis is required to unpick these issues. Therefore, despite this 
chapter advising against attitudes such as TiN being used alone as a proxy for social capital, there remain substantial questions and avenues of research to reconcile the assumed wider benefits of social capital to its theoretical core of norms, trust and networks.

${ }^{1}$ Unless, of course, trust $i$ actually a form of social capital itself (see below)

${ }^{2}$ The negative relationship between local ethnic diversity and attitudes regarding respondents' locale (especially TiN) is highly consistent. However, when local diversity and less locally-specific outcomes are studied (e.g. generalized trust), or the effects of regional or national diversity are explored, far more mixed findings emerge (e.g. Sturgis et al., 2011).

${ }^{3}$ Ego-centric network measures 'obtain information about only that portion of a network in the immediate locality of a given node' (Marsden, 2002, p. 408).

${ }^{4}$ 'Close' is a pre-defined criteria established in the GHS. 'Closeness' was established firstly by whether the individual saw/spoke to the friend 'regularly' (i.e. they were only asked this question if they saw/spoke to a friend at least once every couple of months). Then the questions themselves asked about 'friends' an individual 'felt close to'.

${ }^{5}$ These groups were chosen because of patterns of co-habitation, cultural/social differences and percentage size. However, different aggregations of groups return extremely highly correlated indices $(r=>.95)$.

${ }^{6}$ We found random coefficient models did not significantly improve the model fit

${ }^{7}$ Diversity at the MSOA-level is highly correlated with smaller spatial areas (such as the Lower Super Output Area $(r=.97)$ and Output Area $(r=.94)$. Thus, using the larger spatial scale of the MSOA should not substantially bias our results.

${ }^{8}$ Potentially, high proportions of 'singleton' communities and low level-1 $n$ per level 2 unit can bias multi-level models.

${ }^{9}$ We experimented with a variety of methods to explore the inter-relations between these measures (e.g. oblique and orthogonal rotation, principal components analysis, maximum likelihood, iterated principled factor analysis, and we also applied Horn's Parallel Analysis to test the robustness of our factors).

${ }^{10}$ In a full model, with all controls, predicting 'knowing' and 'speaking to' neighbours, individuals with 'degrees or above' are significantly more likely to 'know' fewer (coef.: $0.058^{* *}$ ), and 'speak' less frequently (coef: $-0.062^{* * *}$ ), to neighbours compared to individuals with 'GCSEs or below'.

${ }^{11}$ To be sure, these findings may be a product of selection-effects. More 'trusting' and 'connected' individuals may be more (less) likely to select-out of (select-into) diverse communities, or less 'trusting'/'connected' individual more (less) likely to select-into (select-out of) diverse communities. Fully discussing these issues is beyond the scope of this chapter. However, see Laurence (2011) or Putnam (2007) for speculation about the possibilities of selection driving diversity's apparent effects.

12 The IMD 2004 coefficient for predicting 'knowing neighbours', in a fully controlled model is $0.092 * * *$. 
${ }^{13}$ We are not necessarily making a causal argument here i.e. that trust is lower in diverse areas because diversity undermines connectivity. It could be that connectivity is lower because diversity undermines trust (as we are using cross-sectional data).

${ }^{14}$ This finding is substantiated in a second dataset. Using the 'Taking Part Survey 200506', in an identically controlled model, Disadvantage negatively predicts TiN (coef.: $0.062 *)$, positively predicts 'knowing neighbours' (coef.: $0.063 * *$ ), and when we control for 'knowing neighbours' in a model predicting TiN, the negative effect of disadvantage on TiN becomes much stronger and more significant (coef:: $-0.099 * * *$ ).

${ }^{15}$ Social capital (that is levels of trust and connectivity) may still be low in disadvantaged areas. It may be that disadvantaged (compared to affluent) areas have lower TiN but both disadvantaged and affluent areas have relatively low levels of social connectivity. Therefore, even though disadvantage is positively associated with connectivity, the differences in connectivity between disadvantaged and affluent communities may be small. However, whilst affluent areas would be 'trusting' but 'disconnected', disadvantaged areas would be 'distrusting' and 'disconnected' i.e. exhibiting low social capital. 


\section{References}

Alesina, A. and La Ferrara, E. (2000), 'Participation in Heterogeneous Communities', Quarterly Journal of Economics, 115(3), 847-904.

Axelrod, R. (1984), The Evolution of Cooperation, New York: Basic Books.

Baumgartner, M. (1988), The Moral Order of the Suburbs, Oxford: Oxford University Press.

Bourdieu, P. (1986), 'The forms of capital', in J. G. Richardson (ed), Handbook for Theory and Research for the Sociology of Education, New York: Greenwood, pp.46-58.

Brehm, J. and Rahn, W.M. (1997), 'Individual Level Evidence for the Causes and Consequences of Social Capital', American Journal of Political Science, 41 (3), 999-1023.

Burt, R. S. (2000), 'The network structure of social capital', Research in Organizational Behavior, 22, 345-423.

Coburn, D. (2000), 'Income inequality, social cohesion and the health status of populations: the role of neo-liberalism', Social Science \& Medicine, 51(1), 135-146.

Coleman, J. S. (1988), 'Social Capital in the Creation of Human Capital', American Journal of Sociology, 94 (supplement), S95-S120.

Collier, P. (2002), 'Social capital and poverty: a microeconomic perspective', in C. Grootaert and T. van Bastelaer (eds), The Role of Social Capital in Development: An Empirical Assessment, Cambridge, U.K: Cambridge University Press, pp. 19-41.

Durlauf, S. N. (2002a), 'On the Empirics of Social Capital', Economic Journal, 112, 459479.

Durlauf, S. N. (2002b), 'Symposium on social capital: Introduction', The Economic 
Journal, 112, 417-418.

Falk, I. and Kilpatrick, S. (2000), 'What is Social Capital? A Study of Interaction in a Rural Community', Sociologia Ruralis, 40 (1), 87-110.

Fieldhouse, E. and Cutts, D. (2010), 'Does Diversity Damage Social Capital? A Comparative Study of Neighbourhood Diversity and Social Capital in the US and Britain', Canadian Journal of Political Science, 43, 289-318.

Fine, B. (2010), Theories of Social Capital: Researchers Behaving Badly, London: Pluto Press

Fukuyama, F. (1995), Trust: The Social Virtues and the Creation of Prosperity, New York: Free Press.

Glaeser, E., D. Laibson, J. A. Scheinkman, and C. L. Soutter (2000), 'What Is Social Capital? The Determinants of Trust and Trustworthiness', Quarterly Journal of Economics, CXV, 811-846.

Harper, R. (2001), Social Capital: a Review of the Literature. London: Office for National Statistics.

Haynes, P. (2009), 'Before going any further with social capital: eight key criticisms to address', Ingenio Working Paper, 2009/2, Valencia.

Kawachi I, Kennedy B, Glass R. (1999), 'Social capital and self-rated health: a contextual analysis', American Journal of Public Health, 89, 1187-93.

Laurence, J. (2011), 'The effect of ethnic diversity and community disadvantage on social cohesion: a multi-level analysis of social capital and interethnic relations in UK communities', European Sociological Review, 27 (1), pp.70-89. 
Letki, N. (2008), 'Does Diversity Erode Social Cohesion? Social Capital and Race in British Neighbourhoods', Political Studies, 56 (1), 99-126.

Li, Y., Pickles, A., and Savage, M. (2005), 'Social capital and social trust in Britain', European Sociological Review, 21(2), 109-123.

Lin, N. (2001), 'Building a network theory of social capital', in N. Lin, K. Cook and R. S. Burt (eds), Social capital: Theory and research, New York: Aldine De Gruyter, pp. 28-51.

Livingston, M., Bailey, N. and Kearns, A. (2010), 'Neighbourhood attachment in deprived areas: evidence from the north of England', Journal of Housing and the Built Environment, 25 (4), 409-427

Marschall, M. and Stolle, D. (2004), 'Race and the city: neighborhood context and the development of generalized trust', Political Behavior, 26, 25-154.

Marsden, P. V. (2002), 'Egocentric and sociocentric measures of network centrality', Social Networks, 24(4), 407-422.

McPherson, M., Smith-Lovin, L. and Cook, J. M. (2001), 'Birds of a Feather: Homophily in Social Networks', Annual Review of Sociology, 27, 415-44.

Messick, D. and Kramer, R. (2001), 'Trust as a Form of Shallow Morality', in K. Cook (ed), Trust in Society, New York: Russell Sage, pp. 80-117

Messick, D. M. and Brewer, M. B. (1983), 'Solving Social Dilemmas: A Review', in L. Wheeler and P. Shaver (eds), Review of Personality and Social Psychology, Beverly Hills: Sage Publications, pp. 11-44

Moore, S., Daniel, M., Paquet, C., Dubé, L., and Gauvin, L. (2009), 'Association of individual network social capital with abdominal adiposity, overweight and obesity', 
Journal of Public Health, 31 (1), 175-183.

Office of the Deputy Prime Minister. (2004), Index of multiple deprivation 2004, http://www.communities.gov.uk

Oliver, J. E. and Mandelberg, T. (2000), 'Reconsidering the Environmental Determinants of White Racial Attitudes', American Journal of Political Science, 44 (3), 574-89.

Paxton, P. (1999), 'Is social capital declining in the United States? A multiple indicator assessment', The American Journal of Sociology, 105 (1), 88-127

Putnam, R. (1995), 'Tuning in, tuning out: the strange disappearance of social capital in America', PS: Politics \& Society, 28, 664-683

Putnam, R. D. (2000), Bowling Alone: The Collapse and Revival of American Community, New York: Simon and Schuster.

Putnam, R. D. (2001), 'Social Capital: Measurement and Consequences', Isuma: Canadian Journal of Policy Research, 2 (1), pp.1-32.

Putnam, R. D. (2007), 'E Pluribus Unum: Diversity and Community in the Twenty-first Century The 2006 Johan Skytte Prize Lecture', Scandinavian Political Studies, 30 (2), 137 174.

Putnam R. D. and Feldstein, L. (2003), Better Together: Restoring the American Community, New York: Simon and Schuster

Ross, C. E., Mirowsky, J. and Pribesh, S. (2001), 'Powerlessness and the Amplification of Threat: Neighborhood Disadvantage, Disorder, and Mistrust', American Sociological Review, 66 (4), 568-91.

Sampson, R. J., Raudenbush, S. and Earls, F. (1997), 'Neighborhoods and Violent Crime: 
A Multilevel Study of Collective Efficacy', Science, 277, 918-24.

Simpson, H. E. (1949), 'Measurement of Diversity', Nature, 163, 688.

Snijders, T. and Bosker, R. (1999), Multilevel Analysis, London: Sage.

Stolle, D., Soroka, S. and Johnston, R. (2008), 'When does diversity erode trust? Neighborhood diversity, interpersonal trust and the mediating effect of social interactions', Political Studies 56 (1), 57-75.

Sturgis, P., Brunton-Smith, I., Read, S., and Allum, N. (2011), 'Does Ethnic Diversity

Erode Trust? Putnam's 'Hunkering Down' Thesis Reconsidered', British Journal of Political Science, 41(1), 57-82.

Uphoff, N. and Wijayaratna, C. M. (2000), 'Demonstrated Benefits from Social Capital: The Productivity of Farmer Organizations in Gal Oya, Sri Lanka', World Development, 28(11), 1875-1890.

Uslaner, E. M. (2010), 'Trust, diversity, and segregation in the United States and the United Kingdom', Comparative Sociology, 10, 221-246. 
Figure 1 - Model of Social Capital (Adapted from: Paxton, 1999)

Associations between Individuals

Trust, Reciprocity, and Positive Emotions

HIGH
LOW

\begin{tabular}{|l|l|}
\hline HIGH & LOW \\
\hline SOCIAL CAPITAL & \\
\hline & \\
& \\
\hline
\end{tabular}


Table 1 - Full summary of social connectivity measures in the 2000-01 GHS

\begin{tabular}{|c|c|c|c|c|c|c|}
\hline & Spatial Dimension & $\frac{\text { Type of }}{\text { Contact }}$ & $\frac{\text { Type of }}{\text { Measure }}$ & Question & \multicolumn{2}{|l|}{ Measurement } \\
\hline 1 & $\begin{array}{l}\text { 'Immediate } \\
\text { Neighbourhood (by } \\
\text { which I mean your } \\
\text { street or block)' }\end{array}$ & Neighbour & $\begin{array}{l}\text { Proportional } \\
\text { Quantity of } \\
\underline{\text { Ties }}\end{array}$ & $\begin{array}{l}\text { 'Would you } \\
\text { say that you } \\
\text { know...?' }\end{array}$ & \multicolumn{2}{|c|}{$\begin{array}{l}\text { 'Most of the people in your } \\
\text { neighbourhood', 'many...', 'a } \\
\text { few...', or 'that you do not know } \\
\text { people in your neighbourhood' }\end{array}$} \\
\hline 2 & $\begin{array}{l}\text { 'Immediate } \\
\text { Neighbourhood (by } \\
\text { which I mean your } \\
\text { street or block)' }\end{array}$ & Neighbour & $\begin{array}{l}\text { Frequency of } \\
\text { interaction } \\
\text { (non-specific) }\end{array}$ & $\begin{array}{l}\text { 'How often do } \\
\text { you speak to } \\
\text { neighbours' }\end{array}$ & \multicolumn{2}{|c|}{$\begin{array}{l}\text { 'not at all in last } 12 \text { months', 'once } \\
\text { or twice a year', 'once every couple } \\
\text { of months', 'once or twice a month', } \\
\text { 'once or twice a week', ' } 3 \text { or } 4 \text { days } \\
\text { a week', ' } 5 \text { or } 6 \text { days a week, 'every } \\
\text { day' }\end{array}$} \\
\hline 3 & $\begin{array}{l}\text { Wider-Community } \\
\text { '(Within a 15-20 } \\
\text { minute walk or 5-10 } \\
\text { minute drive)' }\end{array}$ & $\frac{\text { Close }}{\text { Friends }}$ & $\begin{array}{l}\text { Numerical } \\
\text { Quantity of } \\
\text { Ties }\end{array}$ & \multicolumn{2}{|c|}{$\begin{array}{l}\text { '(Apart from the people you live with,) } \\
\text { how many friends that you feel close to } \\
\text { live' within a } 15-20 \text { minute walk or } 5-10 \\
\text { minute drive, if any?' }\end{array}$} & $\begin{array}{l}\text { 'none', 'one } \\
\text { or two', 'three } \\
\text { or four', 'five } \\
\text { or more' }\end{array}$ \\
\hline 4 & $\begin{array}{l}\text { Wider-Community } \\
\text { '(Within a 15-20 } \\
\text { minute walk or 5-10 } \\
\text { minute drive)' }\end{array}$ & $\frac{\text { Crisis }}{\text { Contacts }}$ & $\begin{array}{l}\text { Numerical } \\
\text { Quantity of } \\
\underline{\text { Ties }}\end{array}$ & \multicolumn{2}{|c|}{$\begin{array}{l}\text { 'If you had a serious personal crisis, how } \\
\text { many people, if any, do you feel you } \\
\text { could turn to for comfort and } \\
\text { support... and how many of these people } \\
\text { live within a } 15-20 \text { minute walk or } 5-10 \\
\text { minute drive, if any?' }\end{array}$} & $\begin{array}{l}\text { Number } \\
\text { entered }(0-15)\end{array}$ \\
\hline 5 & $\begin{array}{l}\text { Wider-Community } \\
\text { '(Within a 15-20 } \\
\text { minute walk or 5-10 } \\
\text { minute drive)' }\end{array}$ & $\frac{\text { Close }}{\text { Relatives }}$ & $\begin{array}{l}\text { Numerical } \\
\text { Quantity of } \\
\underline{\text { Ties }}\end{array}$ & \multicolumn{2}{|c|}{$\begin{array}{l}\text { '(Apart from the people you live with,) } \\
\text { how many relatives that you feel close to } \\
\text { live' within a } 15-20 \text { minute walk or } 5-10 \\
\text { minute drive, if any?' }\end{array}$} & $\begin{array}{l}\text { 'none', 'one } \\
\text { or two', 'three } \\
\text { or four', 'five } \\
\text { or more' }\end{array}$ \\
\hline
\end{tabular}


Table 2 - Factor Analysis of Social Connectivity and TiN measures

\begin{tabular}{lrr}
\hline & Factor 1 & Factor 2 \\
\hline & $\underline{0.482}$ & $\underline{-0.071}$ \\
Trust in Neighbours & 0.096 & 0.489 \\
Number of local close friends & 0.103 & 0.597 \\
Number of local crisis contacts & 0.548 & 0.011 \\
Proportion of neighbours known & 0.428 & 0.076 \\
Frequency of speaking to neighbours & -0.074 & 0.531 \\
Number of close relatives in local area & & \\
& 0.85 & 0.81 \\
\hline
\end{tabular}

Notes: Orthogonal Varimax Rotation (Kaiser On) 
Table 3 - Relationship between social connectivity measures and trust in neighbours; $\underline{\text { standardised coefficients }}$

\begin{tabular}{|c|c|c|c|c|c|c|}
\hline $\begin{array}{l}\text { Dependent Variable: } \\
\text { Neighbour Trust }\end{array}$ & Model 1 & Model 2 & Model 3 & Model 4 & Model 5 & Model 6 \\
\hline HH Income & $\begin{array}{l}0.072 * \\
(0.034)\end{array}$ & $\begin{array}{l}0.0769 * \\
(0.033)\end{array}$ & $\begin{array}{l}0.0759 * \\
(0.0344)\end{array}$ & $\begin{array}{l}0.0713 * \\
(0.0343)\end{array}$ & $\begin{array}{l}0.105 * * \\
(0.0379)\end{array}$ & $\begin{array}{l}0.0962 * \\
(0.0409)\end{array}$ \\
\hline \multicolumn{7}{|l|}{ Cf. No Qualifications } \\
\hline Other/apprentices to GCSE 1-4 & $\begin{array}{l}-0.008 \\
(0.0300)\end{array}$ & $\begin{array}{l}-0.00729 \\
(0.0300)\end{array}$ & $\begin{array}{l}-0.0115 \\
(0.0301)\end{array}$ & $\begin{array}{l}-0.0123 \\
(0.0303)\end{array}$ & $\begin{array}{l}-0.0168 \\
(0.0302)\end{array}$ & $\begin{array}{l}-0.0117 \\
(0.0313)\end{array}$ \\
\hline GCSEs $5+/ 1$ or more A-level & $\begin{array}{l}0.0477 \\
(0.0304)\end{array}$ & $\begin{array}{l}0.0488 \\
(0.0303)\end{array}$ & $\begin{array}{l}0.0475 \\
(0.0302)\end{array}$ & $\begin{array}{l}0.0434 \\
(0.0302)\end{array}$ & $\begin{array}{c}0.0524+ \\
(0.0306)\end{array}$ & $\begin{array}{l}0.0604+ \\
(0.0330)\end{array}$ \\
\hline 2 or more A LEVELS & $\begin{array}{c}0.0548+ \\
(0.0310)\end{array}$ & $\begin{array}{c}0.0566+ \\
(0.0311)\end{array}$ & $\begin{array}{l}0.0543+ \\
(0.0312)\end{array}$ & $\begin{array}{l}0.0507 \\
(0.0312)\end{array}$ & $\begin{array}{c}0.0586+ \\
(0.0315)\end{array}$ & $\begin{array}{l}0.0883 * * \\
(0.0329)\end{array}$ \\
\hline Below Degree & $\begin{array}{l}0.0139 \\
(0.0296)\end{array}$ & $\begin{array}{l}0.0168 \\
(0.0297)\end{array}$ & $\begin{array}{l}0.0121 \\
(0.0296)\end{array}$ & $\begin{array}{l}0.00794 \\
(0.0297)\end{array}$ & $\begin{array}{l}0.00296 \\
(0.0300)\end{array}$ & $\begin{array}{l}0.0246 \\
(0.0317)\end{array}$ \\
\hline Degree+ & $\begin{array}{l}0.124 * * * \\
(0.0332)\end{array}$ & $\begin{array}{l}0.134 * * * \\
(0.0338)\end{array}$ & $\begin{array}{l}0.133 * * * \\
(0.0340)\end{array}$ & $\begin{array}{l}0.133 * * * \\
(0.0340)\end{array}$ & $\begin{array}{l}0.149 * * * \\
(0.0348)\end{array}$ & $\begin{array}{l}0.190 * * * \\
(0.0372)\end{array}$ \\
\hline Other & $\begin{array}{l}-0.0824+ \\
(0.0434)\end{array}$ & $\begin{array}{l}-0.0827+ \\
(0.0434)\end{array}$ & $\begin{array}{c}-0.0747+ \\
(0.0435)\end{array}$ & $\begin{array}{l}-0.0808+ \\
(0.0437)\end{array}$ & $\begin{array}{l}-0.0723 \\
(0.0448)\end{array}$ & $\begin{array}{l}-0.0493 \\
(0.0467)\end{array}$ \\
\hline \multicolumn{7}{|l|}{ Cf. Employed } \\
\hline Home-person & $\begin{array}{l}-0.0101 \\
(0.0296)\end{array}$ & $\begin{array}{l}-0.00912 \\
(0.0296)\end{array}$ & $\begin{array}{l}-0.00598 \\
(0.0294)\end{array}$ & $\begin{array}{l}-0.00924 \\
(0.0293)\end{array}$ & $\begin{array}{l}-0.0203 \\
(0.0294)\end{array}$ & $\begin{array}{l}-0.00115 \\
(0.0299)\end{array}$ \\
\hline L/T Disabled & $\begin{array}{l}0.0333 \\
(0.0312)\end{array}$ & $\begin{array}{l}0.0336 \\
(0.0311)\end{array}$ & $\begin{array}{l}0.0322 \\
(0.0313)\end{array}$ & $\begin{array}{l}0.0366 \\
(0.0311)\end{array}$ & $\begin{array}{l}0.0184 \\
(0.0313)\end{array}$ & $\begin{array}{l}-0.00526 \\
(0.0317)\end{array}$ \\
\hline Retired & $\begin{array}{l}0.0288 \\
(0.0442)\end{array}$ & $\begin{array}{l}0.0264 \\
(0.0443)\end{array}$ & $\begin{array}{l}0.0258 \\
(0.0446)\end{array}$ & $\begin{array}{l}0.0205 \\
(0.0447)\end{array}$ & $\begin{array}{l}-0.0138 \\
(0.0452)\end{array}$ & $\begin{array}{l}-0.00144 \\
(0.0480)\end{array}$ \\
\hline Unemployed & $\begin{array}{l}0.0188 \\
(0.0286)\end{array}$ & $\begin{array}{l}0.0194 \\
(0.0286)\end{array}$ & $\begin{array}{l}0.0136 \\
(0.0284)\end{array}$ & $\begin{array}{l}0.0138 \\
(0.0284)\end{array}$ & $\begin{array}{l}0.0140 \\
(0.0290)\end{array}$ & $\begin{array}{l}0.0165 \\
(0.0285)\end{array}$ \\
\hline Other Status & $\begin{array}{l}0.0229 \\
(0.0288)\end{array}$ & $\begin{array}{l}0.0243 \\
(0.0288)\end{array}$ & $\begin{array}{l}0.0240 \\
(0.0292)\end{array}$ & $\begin{array}{l}0.0218 \\
(0.0295)\end{array}$ & $\begin{array}{l}0.0226 \\
(0.0295)\end{array}$ & $\begin{array}{l}0.00352 \\
(0.0300)\end{array}$ \\
\hline Age & $\begin{array}{l}0.681 * * * \\
(0.0523)\end{array}$ & $\begin{array}{l}0.700 * * * \\
(0.0532)\end{array}$ & $\begin{array}{l}0.713 * * * \\
(0.0532)\end{array}$ & $\begin{array}{l}0.738 * * * \\
(0.0538)\end{array}$ & $\begin{array}{l}0.684 * * * \\
(0.0545)\end{array}$ & $\begin{array}{l}0.688 * * * \\
(0.0578)\end{array}$ \\
\hline Female & $\begin{array}{l}0.0424+ \\
(0.0257)\end{array}$ & $\begin{array}{l}0.0414 \\
(0.0258)\end{array}$ & $\begin{array}{l}0.0374 \\
(0.0260)\end{array}$ & $\begin{array}{l}0.0421 \\
(0.0261)\end{array}$ & $\begin{array}{l}0.0355 \\
(0.0266)\end{array}$ & $\begin{array}{l}-0.00763 \\
(0.0277)\end{array}$ \\
\hline Married & $\begin{array}{l}0.0869 * * \\
(0.0280)\end{array}$ & $\begin{array}{l}0.0815 * * \\
(0.0282)\end{array}$ & $\begin{array}{l}0.0736 * * \\
(0.0284)\end{array}$ & $\begin{array}{l}0.0850 * * \\
(0.0285)\end{array}$ & $\begin{array}{l}0.0625^{*} \\
(0.0289)\end{array}$ & $\begin{array}{l}0.0423 \\
(0.0303)\end{array}$ \\
\hline Number of children in $\mathrm{HH}$ & $\begin{array}{l}0.0846^{* *} \\
(0.0272)\end{array}$ & $\begin{array}{l}0.0818 * * \\
(0.0271)\end{array}$ & $\begin{array}{l}0.0752 * * \\
(0.0273)\end{array}$ & $\begin{array}{l}0.0684 * \\
(0.0273)\end{array}$ & $\begin{array}{l}0.0187 \\
(0.0276)\end{array}$ & $\begin{array}{l}-0.0326 \\
(0.0286)\end{array}$ \\
\hline
\end{tabular}




\begin{tabular}{|c|c|c|c|c|c|c|}
\hline \multicolumn{7}{|l|}{ Cf. White } \\
\hline Black & $\begin{array}{l}-0.0967 * * * \\
(0.0253)\end{array}$ & $\begin{array}{l}-0.0974 * * * \\
(0.0253)\end{array}$ & $\begin{array}{l}-0.0932 * * * \\
(0.0252)\end{array}$ & $\begin{array}{l}-0.0926 * * * \\
(0.0251)\end{array}$ & $\begin{array}{l}-0.0978 * * * \\
(0.0248)\end{array}$ & $\begin{array}{l}-0.0801 * * \\
(0.0257)\end{array}$ \\
\hline Indian & $\begin{array}{l}-0.0769 * * \\
(0.0268)\end{array}$ & $\begin{array}{l}-0.0789 * * \\
(0.0270)\end{array}$ & $\begin{array}{l}-0.0793 * * \\
(0.0260)\end{array}$ & $\begin{array}{l}-0.0748 * * \\
(0.0255)\end{array}$ & $\begin{array}{l}-0.0808 * * \\
(0.0254)\end{array}$ & $\begin{array}{l}-0.0816^{* *} \\
(0.0249)\end{array}$ \\
\hline Pakistani/Bangladeshi & $\begin{array}{l}-0.0374 \\
(0.0300)\end{array}$ & $\begin{array}{l}-0.0384 \\
(0.0301)\end{array}$ & $\begin{array}{l}-0.0359 \\
(0.0306)\end{array}$ & $\begin{array}{l}-0.0349 \\
(0.0310)\end{array}$ & $\begin{array}{l}-0.0321 \\
(0.0286)\end{array}$ & $\begin{array}{l}-0.0350 \\
(0.0302)\end{array}$ \\
\hline Other & $\begin{array}{l}-0.0700^{* *} \\
(0.0234)\end{array}$ & $\begin{array}{l}-0.0703 * * \\
(0.0234)\end{array}$ & $\begin{array}{l}-0.0655^{* *} \\
(0.0236)\end{array}$ & $\begin{array}{l}-0.0596 * \\
(0.0241)\end{array}$ & $\begin{array}{l}-0.0533^{*} \\
(0.0240)\end{array}$ & $\begin{array}{l}-0.0489 * \\
(0.0245)\end{array}$ \\
\hline \multicolumn{7}{|l|}{ Cf. Own (Mortgage) } \\
\hline Own outright & $\begin{array}{l}0.0320 \\
(0.0330)\end{array}$ & $\begin{array}{l}0.0345 \\
(0.0331)\end{array}$ & $\begin{array}{l}0.0334 \\
(0.0331)\end{array}$ & $\begin{array}{l}0.0306 \\
(0.0333)\end{array}$ & $\begin{array}{l}0.0186 \\
(0.0341)\end{array}$ & $\begin{array}{l}0.0154 \\
(0.0359)\end{array}$ \\
\hline LA Tenure & $\begin{array}{l}-0.204 * * * \\
(0.0322)\end{array}$ & $\begin{array}{l}-0.204 * * * \\
(0.0321)\end{array}$ & $\begin{array}{l}-0.206^{* * *} \\
(0.0320)\end{array}$ & $\begin{array}{l}-0.204 * * * \\
(0.0319)\end{array}$ & $\begin{array}{l}-0.230 * * * \\
(0.0322)\end{array}$ & $\begin{array}{l}-0.256^{* * *} \\
(0.0321)\end{array}$ \\
\hline HA Tenure & $\begin{array}{l}-0.0381 \\
(0.0282)\end{array}$ & $\begin{array}{l}-0.0363 \\
(0.0282)\end{array}$ & $\begin{array}{l}-0.0386 \\
(0.0283)\end{array}$ & $\begin{array}{l}-0.0371 \\
(0.0285)\end{array}$ & $\begin{array}{l}-0.0728 * \\
(0.0298)\end{array}$ & $\begin{array}{l}-0.105 * * * \\
(0.0312)\end{array}$ \\
\hline Tenure (Other) & $\begin{array}{l}-0.0348 \\
(0.0290)\end{array}$ & $\begin{array}{l}-0.0322 \\
(0.0289)\end{array}$ & $\begin{array}{l}-0.0352 \\
(0.0291)\end{array}$ & $\begin{array}{l}-0.0325 \\
(0.0293)\end{array}$ & $\begin{array}{l}-0.0285 \\
(0.0293)\end{array}$ & $\begin{array}{l}0.00867 \\
(0.0304)\end{array}$ \\
\hline Not born in UK & $\begin{array}{l}-0.0178 \\
(0.0323)\end{array}$ & $\begin{array}{l}-0.0148 \\
(0.0324)\end{array}$ & $\begin{array}{l}-0.0134 \\
(0.0320)\end{array}$ & $\begin{array}{l}-0.0188 \\
(0.0320)\end{array}$ & $\begin{array}{l}-0.00428 \\
(0.0319)\end{array}$ & $\begin{array}{l}0.00932 \\
(0.0334)\end{array}$ \\
\hline \multicolumn{7}{|l|}{ Cf. Non-Manual SEG } \\
\hline Manual SEG & $\begin{array}{l}-0.0435 \\
(0.0297)\end{array}$ & $\begin{array}{l}-0.0459 \\
(0.0296)\end{array}$ & $\begin{array}{l}-0.0499+ \\
(0.0299)\end{array}$ & $\begin{array}{l}-0.0526+ \\
(0.0298)\end{array}$ & $\begin{array}{l}-0.0685^{*} \\
(0.0300)\end{array}$ & $\begin{array}{l}-0.0775^{*} \\
(0.0312)\end{array}$ \\
\hline Never Worked & $\begin{array}{l}-0.0752 * \\
(0.0302)\end{array}$ & $\begin{array}{l}-0.0760 * \\
(0.0301)\end{array}$ & $\begin{array}{l}-0.0777 * * \\
(0.0297)\end{array}$ & $\begin{array}{l}-0.0744 * \\
(0.0298)\end{array}$ & $\begin{array}{l}-0.0760 * \\
(0.0308)\end{array}$ & $\begin{array}{l}-0.0691 * \\
(0.0312)\end{array}$ \\
\hline Student SEG & $\begin{array}{l}0.0591+ \\
(0.0303)\end{array}$ & $\begin{array}{l}0.0615^{*} \\
(0.0303)\end{array}$ & $\begin{array}{l}0.0590 * \\
(0.0301)\end{array}$ & $\begin{array}{l}0.0516+ \\
(0.0302)\end{array}$ & $\begin{array}{l}0.0456 \\
(0.0299)\end{array}$ & $\begin{array}{l}0.0442 \\
(0.0311)\end{array}$ \\
\hline years in Area & $\begin{array}{l}0.131 * * * \\
(0.0308)\end{array}$ & $\begin{array}{l}0.113 * * * \\
(0.0316)\end{array}$ & $\begin{array}{l}0.0841 * * \\
(0.0318)\end{array}$ & $\begin{array}{l}0.0611+ \\
(0.0319)\end{array}$ & $\begin{array}{l}0.0529+ \\
(0.0321)\end{array}$ & $\begin{array}{l}-0.0450 \\
(0.0311)\end{array}$ \\
\hline \multicolumn{7}{|l|}{ Cf. Other Regions } \\
\hline London & $\begin{array}{l}-0.114 * * * \\
(0.0263)\end{array}$ & $\begin{array}{l}-0.110 * * * \\
(0.0264)\end{array}$ & $\begin{array}{l}-0.107 * * * \\
(0.0262)\end{array}$ & $\begin{array}{l}-0.105^{* * *} \\
(0.0263)\end{array}$ & $\begin{array}{l}-0.0961 * * * \\
(0.0272)\end{array}$ & $\begin{array}{l}-0.0588 * \\
(0.0283)\end{array}$ \\
\hline Wales & $\begin{array}{l}0.179 * * * \\
(0.0191)\end{array}$ & $\begin{array}{l}0.177 * * * \\
(0.0190)\end{array}$ & $\begin{array}{l}0.177 * * * \\
(0.0196)\end{array}$ & $\begin{array}{l}0.157 * * * \\
(0.0202)\end{array}$ & $\begin{array}{l}0.0447 * \\
(0.0215)\end{array}$ & $\begin{array}{l}0.00329 \\
(0.0196)\end{array}$ \\
\hline Local Close Relatives & & $\begin{array}{l}0.063 * \\
(0.0278)\end{array}$ & $\begin{array}{l}-0.00906 \\
(0.0272)\end{array}$ & $\begin{array}{l}-0.019 \\
(0.0273)\end{array}$ & $\begin{array}{l}-0.037 \\
(0.0289)\end{array}$ & $\begin{array}{l}0.000 \\
(0.031)\end{array}$ \\
\hline Local Crisis Contacts & & & $\begin{array}{l}0.216 * * * \\
(0.031)\end{array}$ & $\begin{array}{l}0.153 * * * \\
(0.032)\end{array}$ & $\begin{array}{l}0.111 * * * \\
(0.032)\end{array}$ & $\begin{array}{l}0.071 * \\
(0.0329)\end{array}$ \\
\hline Local Close Friends & & & & $\begin{array}{l}0.167 * * * \\
(0.0238)\end{array}$ & $\begin{array}{l}0.11 * * * \\
(0.0285)\end{array}$ & $\begin{array}{l}0.04 \\
(0.0289)\end{array}$ \\
\hline Speak to Neighbours & & & & & $\begin{array}{l}0.487 * * * \\
(0.03)\end{array}$ & $\begin{array}{l}0.211 * * * \\
(0.032)\end{array}$ \\
\hline
\end{tabular}




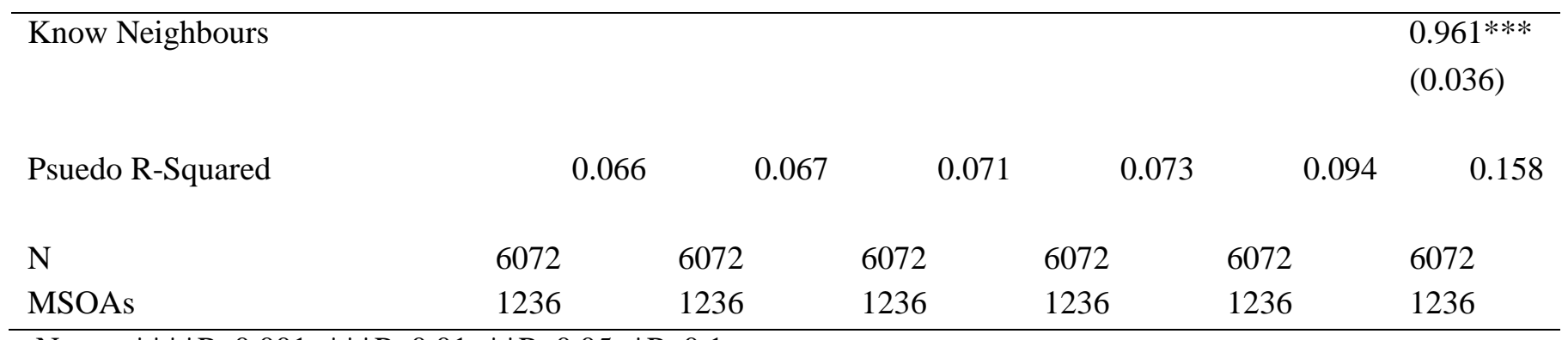

Notes: $* * * * \mathrm{P}<0.001 ; * * * \mathrm{P}<0.01 ; * * \mathrm{P}<0.05 ; * \mathrm{P}<0.1$ 
Table 4 - Cross-tabulation between proportion of neighbours known and trusted

\begin{tabular}{lccc}
\hline & $\begin{array}{l}\text { Trust none/a few of } \\
\text { your neighbours }\end{array}$ & $\begin{array}{l}\text { Trust many/most } \\
\text { of your neighbours }\end{array}$ \\
\hline $\begin{array}{l}\text { Know none/a few } \\
\text { of your neighbours }\end{array}$ & $61 \%$ & $39 \%$ & $100 \%$ \\
Know Many/Most & $\underline{80 \%}$ & $\underline{35 \%}$ & \\
of your neighbours & $17 \%$ & $83 \%$ & $100 \%$ \\
& $\underline{20 \%}$ & $\underline{65 \%}$ & \\
& $\underline{100 \%}$ & $\underline{100 \%}$ & \\
\hline
\end{tabular}


Table 5 - Mediating effect of social connectivity; standardised coefficients

\begin{tabular}{|c|c|c|c|c|c|c|}
\hline $\begin{array}{l}\text { Dependent Variable: Neighbour } \\
\text { Trust }\end{array}$ & Model 1 & Model 2 & Model 3 & Model 4 & Model 5 & Model 6 \\
\hline \multicolumn{7}{|l|}{$\underline{\text { Community-level Variables }}$} \\
\hline Density (MSOA) & $\begin{array}{c}-0.0676+ \\
(0.0387)\end{array}$ & $\begin{array}{c}-0.0661+ \\
(0.0388)\end{array}$ & $\begin{array}{c}-0.0691+ \\
(0.0385)\end{array}$ & $\begin{array}{l}-0.0756 * \\
(0.0385)\end{array}$ & $\begin{array}{c}-0.0662+ \\
(0.0395)\end{array}$ & $\begin{array}{c}-0.0126 \\
(0.0401)\end{array}$ \\
\hline Turnover (MSOA) & $\begin{array}{l}-0.0367 \\
(0.0287)\end{array}$ & $\begin{array}{l}-0.0304 \\
(0.0288)\end{array}$ & $\begin{array}{l}-0.0336 \\
(0.0287)\end{array}$ & $\begin{array}{l}-0.0384 \\
(0.0284)\end{array}$ & $\begin{array}{l}-0.0256 \\
(0.0300)\end{array}$ & $\begin{array}{l}0.00800 \\
(0.0292)\end{array}$ \\
\hline$\% 65+(\mathrm{MSOA})$ & $\begin{array}{c}0.0687 * \\
(0.0338)\end{array}$ & $\begin{array}{c}0.0690 * \\
(0.0337)\end{array}$ & $\begin{array}{l}0.0704 * \\
(0.0339)\end{array}$ & $\begin{array}{l}0.0715 * \\
(0.0335)\end{array}$ & $\begin{array}{l}0.0819 * \\
(0.0344)\end{array}$ & $\begin{array}{l}0.0880 * \\
(0.0343)\end{array}$ \\
\hline \multicolumn{7}{|l|}{ cf. Village (MSOA) } \\
\hline Town (MSOA) & $\begin{array}{c}-0.00902 \\
(0.0400)\end{array}$ & $\begin{array}{l}-0.0105 \\
(0.0399)\end{array}$ & $\begin{array}{l}-0.0142 \\
(0.0408)\end{array}$ & $\begin{array}{l}-0.0171 \\
(0.0404)\end{array}$ & $\begin{array}{l}-0.0194 \\
(0.0399)\end{array}$ & $\begin{array}{c}0.0109 \\
(0.0412)\end{array}$ \\
\hline Urban (MSOA) & $\begin{array}{c}- \\
0.219 * * * \\
(0.0426)\end{array}$ & $\begin{array}{c}- \\
0.229 * * * \\
(0.0427)\end{array}$ & $\begin{array}{c}- \\
0.231 * * * \\
(0.0433)\end{array}$ & $\begin{array}{c}- \\
0.234 * * * \\
(0.0432)\end{array}$ & $\begin{array}{c}- \\
0.238 * * * \\
(0.0434)\end{array}$ & $\begin{array}{l}-0.135^{* *} \\
(0.0447)\end{array}$ \\
\hline IMD 2004 & $\begin{array}{c}- \\
0.165 * * * \\
(0.0337)\end{array}$ & $\begin{array}{c}- \\
0.171 * * * \\
(0.0337)\end{array}$ & $\begin{array}{c}- \\
0.165 * * * \\
(0.0334)\end{array}$ & $\begin{array}{c}- \\
0.154 * * * \\
(0.0335)\end{array}$ & $\begin{array}{c}- \\
0.184 * * * \\
(0.0348)\end{array}$ & $\begin{array}{c}- \\
0.232 * * * \\
(0.0332)\end{array}$ \\
\hline Simpson's Diversity (MSOA) & $\begin{array}{l}-0.122 * \\
(0.0535)\end{array}$ & $\begin{array}{l}-0.114 * \\
(0.0533)\end{array}$ & $\begin{array}{l}-0.107 * \\
(0.0533)\end{array}$ & $\begin{array}{l}-0.106^{*} \\
(0.0527)\end{array}$ & $\begin{array}{c}-0.0973+ \\
(0.0548)\end{array}$ & $\begin{array}{c}-0.0803 \\
(0.0542)\end{array}$ \\
\hline Local Close Relatives & & $\begin{array}{c}0.0832 * * \\
(0.0278)\end{array}$ & $\begin{array}{c}0.0121 \\
(0.0293)\end{array}$ & $\begin{array}{l}0.00103 \\
(0.0294)\end{array}$ & $\begin{array}{l}-0.00645 \\
(0.0300)\end{array}$ & $\begin{array}{c}0.0235 \\
(0.0316)\end{array}$ \\
\hline Local Crisis Contacts & & & $\begin{array}{c}0.208 * * * \\
(0.0314)\end{array}$ & $\begin{array}{c}0.145^{* * *} \\
(0.0329)\end{array}$ & $\begin{array}{l}0.103 * * \\
(0.0326)\end{array}$ & $\begin{array}{c}0.0644+ \\
(0.0332)\end{array}$ \\
\hline Local Close Friends & & & & $\begin{array}{c}0.169 * * * \\
(0.0282)\end{array}$ & $\begin{array}{c}0.110 * * * \\
(0.0288)\end{array}$ & $\begin{array}{c}0.0368 \\
(0.0293)\end{array}$ \\
\hline Speak to Neighbours & & & & & $\begin{array}{c}0.499 * * * \\
(0.0297)\end{array}$ & $\begin{array}{c}0.234 * * * \\
(0.0326)\end{array}$ \\
\hline Know Neighbours & & & & & & $\begin{array}{c}0.930 * * * \\
(0.0361)\end{array}$ \\
\hline Pseudo R-Squared & 0.082 & 0.083 & 0.086 & 0.089 & 0.11 & 0.169 \\
\hline Individuals & 6072 & 6072 & 6072 & 6072 & 6072 & 6072 \\
\hline MSOAs & 1236 & 1236 & 1236 & 1236 & 1236 & 1236 \\
\hline
\end{tabular}

Notes: $* * * * \mathrm{P}<0.001 ; * * * \mathrm{P}<0.01 ; * * \mathrm{P}<0.05 ; * \mathrm{P}<0.1$; all individual-level controls included in model 